\title{
SKEMA TRANSFER PRICING UNTUK PENGALIHAN LABA
}

\author{
TRANSFER PRICING SCHEME FOR PROFIT SHIFTING
}

\author{
Pratikto Winardi Bakhram*), Hermanto Siregar ${ }^{* * *}$, dan Moch. Hadi Santoso $\left.{ }^{* * *}\right)$ \\ *) Sekolah Bisnis, IPB University \\ Jl. Padjajaran, Bogor, Indonesia 16151, Indonesia \\ ${ }^{* *}$ Departemen Ilmu Ekonomi, Fakultas Ekonomi dan Manajemen, IPB University \\ Jl. Agatis Kampus IPB Dramaga, Bogor 16680, Indonesia \\ $\left.{ }^{* * *}\right)$ Prasetya Mulya Jakarta \\ Jl. R.A.Kartini, Cilandak, Jakarta Selatan, Jakarta 12430, Indonesia
}

\begin{abstract}
More than 60\% of world transactions used a transfer pricing scheme. Transfer pricing for tax avoidance is not in accordance with domestic Indonesian tax rules. This study aim to generate understanding about transfer pricing concept, determine transfer pricing risk factors, identify transfer pricing schemes, and explain transfer pricing risk management. Descriptive analysis method based on secondary data and literature studies applied in this research. This research shows that transfer pricing should be based on the arm's length principle. Factors that determine transfer pricing risks are inter-company transactions, tax rates, and foreign ownership. Transfer pricing can be implemented in intercompany transactions schemes related to sales, intangible asset, loan and services through one or a combination of several types of inter-company transactions. Transfer pricing risk management can be carried out through law enforcement, access of information agreement, and development of a transfer pricing risk-based monitoring system. The Directorate General of Taxes needs to pay attention to taxpayers who have affiliated transactions, lower tax rates, and foreign ownership in monitoring the risk of transfer pricing. Business groups also need to to fulfill the arm's length principle in the transfer pricing scheme in order to comply with the regulation.
\end{abstract}

Keywords: business groups, inter-company transactions, profit shifting, tax avoidance, transfer pricing

\begin{abstract}
Abstrak: Lebih dari 60\% transaksi dunia terkait skema transfer pricing. Transfer pricing untuk penghindaran pajak tidak sesuai dengan ketentuan perpajakan di Indonesia. Penelitian ini bertujuan membangun pemahaman konsep transfer pricing, menentukan faktorfaktor risiko transfer pricing, mengidentifikasi skema transfer pricing, dan menjelaskan penanganan risiko transfer pricing. Metode analisis deskriptif berdasarkan data sekunder dan studi literatur diterapkan pada penelitian ini. Penelitian ini menunjukan bahwa transfer pricing harus memenuhi prinsip kewajaran dan kelaziman usaha. Faktor-faktor yang memengaruhi risiko transfer pricing adalah jenis-jenis transaksi antar afiliasi, tarif pajak, dan kepemilikan asing. Transfer pricing dapat diterapkan dalam skema transaksi afiliasi berupa penjualan, aset tidak berwujud, pinjaman dan jasa melalui satu jenis transaksi afiliasi maupun kombinasi beberapa jenis transaksi afiliasi. Pengelolaan risiko transfer pricing dapat dilakukan melalui implementasi hukum, kerjasama akses informasi, dan pembangunan sistem pengawasan berbasis risiko transfer pricing. Direktorat Jenderal Pajak perlu memperhatikan wajib pajak yang memiliki transaksi afiliasi, tarif pajak rendah, dan kepemilikan pihak asing dalam pengawasan risiko transfer pricing. Grup usaha juga harus memenuhi the arm's length principle dalam skema transfer pricing agar sesuai dengan ketentuan yang berlaku.
\end{abstract}

Kata kunci: grup usaha, pengalihan laba, penghindaran pajak, transaksi afiliasi, transfer pricing

${ }^{1}$ Corresponding author:

Email: pratikto.winardi.bakhram@gmail.com 


\section{PENDAHULUAN}

Transaksi afiliasi dengan skema transfer pricing mencakup sekitar $60 \%$ transaksi perusahaan multinasional di dunia (Darussalam et al. 2013). Transaksi afiliasi dengan skema transfer pricing secara signifikan terkait dengan penghindaran pajak perusahaan (Adegbite dan Bojuwon, 2019; Amidu et al. 2019). Penghindaran pajak memiliki risiko menjatuhkan harga saham dimasa depan (Li et al. 2016). Transfer pricing digunakan untuk meminimalkan kewajiban perpajakan grup dengan memanfaatkan celah ketentuan perpajakan domestik dan internasional (Huda et al. 2017). Transfer pricing dapat dilakukan dengan berbagai skema transaksi afiliasi seperti skema double irish, skema cost sharing agreement (Barker et al. 2017), dan skema restrukturisasi bisnis (Stoddard dan Templeton, 2008).

Di Indonesia, transaksi afiliasi merupakan aksi korporasi dengan tingkat keterjadian tertinggi pada Bursa Efek Indonesia (Tambunan et al. 2016). Transaksi afiliasi untuk penghindaran pajak melalui transfer pricing tidak sesuai dengan ketentuan perpajakan di Indonesia (UU 2008). Implementasi UU (2018) dalam penanganan risiko transfer pricing oleh otoritas pajak di Indonesia memiliki perbedaan tantangan dengan negara maju (OECD, 2012). Otoritas pajak di Indonesia perlu memiliki pengetahuan yang baik terkait transfer pricing serta memahami faktor-faktor risiko transfer pricing yang mungkin muncul agar dapat membuat kebijakan yang sesuai dengan risiko transfer pricing di Indonesia (OECD, 2012). Namun, belum ditemukan penelitian terdahulu yang secara simultan membahas konsep transfer pricing, apa saja faktor-faktor yang memiliki pengaruh terhadap risiko transfer pricing, bagaimana skema-skema transfer pricing diimplementasikan, dan bagaimana penanganan risiko transfer pricing dengan observasi mencakup perusahaan terdaftar maupun tidak terdaftar pada Bursa Efek Indonesia yang berdomisili di seluruh wilayah Indonesia.

Penelitian ini memiliki tujuan untuk membangun pemahaman konsep transfer pricing, mengidentifikasi faktor-faktor risiko transfer pricing, mengidentifikasi skema transfer pricing, dan mengidentifikasi penanganan risiko transfer pricing. Penelitian ini terbatas pada analisis faktor-faktor risiko transfer pricing berupa transaksi afiliasi, tarif pajak dan kepemilikan asing melalui statistik deskriptif serta identifikasi skema transfer pricing atas transaksi afiliasi berupa penjualan, aset tidak berwujud, pinjaman dan jasa melalui studi literatur.

\section{METODE PENELITIAN}

Penelitian dilakukan pada bulan Oktober sampai Desember 2020 di Kantor Pusat Direktorat Jenderal Pajak dengan data diperoleh secara formal, hanya untuk tujuan penelitian, dan dijaga kerahasiaannya. Penelitian menggunakan analisis statistik deskriptif dan studi literatur. Analisis statistika deskriptif diterapkan pada data sekunder yang dikumpulkan secara purposive sample, dengan kriteria, yaitu (1) perusahaan yang memiliki transaksi afiliasi; (2) perusahaan yang memiliki nilai peredaran usaha; dan (3) perusahaan dengan perhitungan pajak penghasilan non-final. Penelitian ini mencakup 7.672 observasi untuk tujuh tahun pajak yaitu Tahun 2012 sampai dengan Tahun 2018.

Pemahaman konsep transfer pricing dan identifikasi faktor-faktor yang mempengaruhi risiko transfer pricing dilakukan melalui studi literatur. Hasil studi literatur diimplementasikan dalam analisis faktor-faktor risiko transfer pricing terhadap 7.672 data observasi melalui analisis statistik deskriptif serta identifikasi penerapan skema transfer pricing. Penelitian juga dilakukan dalam mengidentifikasi bagaimana penanganan risiko transfer pricing oleh otoritas pajak. Kerangka pemikiran dapat dilihat pada Gambar 1.

\section{HASIL}

\section{Konsep Transfer Pricing}

Transfer pricing merupakan suatu penetapan harga terkait transaksi afiliasi oleh suatu perusahaan (OECD 2017). Negara-negara OECD telah menyepakati suatu standar dalam menentukan penetapan harga untuk keperluan pajak yaitu transaksi antara pihak afiliasi harus memenuhi prinsip kewajaran dan kelaziman usaha (arm's length principle) (OECD, 2017).

Salah satu alat untuk mengukur pemenuhan arm's length principle adalah dengan analisis kesebandingan yang merupakan jantung dari penerapan arm's length principle (OECD, 2017). Terdapat lima faktor kesebandingan dalam analisis kesebandingan, yaitu: (1) ketentuan kontrak transaksi; (2) fungsi, aset dan 
risiko; (3) karakteristik barang; (4) keadaan ekonomi; (5) strategi bisnis (OECD, 2017).

Feinschreiber dan Kent (2012) menjelaskan bahwa wajib pajak maupun otoritas pajak harus memenuhi dua persyaratan dalam memilih pihak yang diuji (tested party), yaitu (1) pihak yang diuji dapat diaplikasikan oleh wajib pajak maupun otoritas pajak dengan cara yang andal; dan (2) wajib pajak maupun otoritas pajak harus memilih pihak yang diuji ketika kedua belah pihak dapat menemukan pembanding yang paling dapat diandalkan. Umumnya tested party adalah pihak dengan fungsi yang lebih sederhana.

Terdapat metode-metode yang digunakan dalam pengukuran pemenuhan arm's length principle yaitu traditional transaction methods dan transactional profit methods (OECD, 2017). Traditional transaction methods terdiri dari Comparable Uncontrolled Price Method (CUP), Resale Price Method, dan Cost Plus Method. Transactional profit methods terdiri dari Transactional Net Margin Method (TNMM) dan Transactional Profit Split Method (OECD, 2017).

\section{Faktor-faktor Risiko Transfer Pricing}

\section{Transaksi Afiliasi}

Semakin tinggi transaksi afiliasi maka semakin besar penghindaran pajak yang dilakukan perusahaan (Sari et al. 2017). Perusahaan multinasional menurunkan beban pajak melalui transfer pricing (Kiesewetter et al. 2018). Transfer pricing dapat diterapkan dengan berbagai jenis transaksi afiliasi yaitu transaksi penjualan aset berwujud atau aset tidak berwujud, transaksi pemanfaatan aset tidak berwujud, transaksi jasa, dan transaksi biaya pinjaman (Permen, 2020). Aset tidak berwujud dan kompleksitas struktur rantai pasok suatu grup usaha merupakan penentu signifikan dari aktivitas pengalihan laba melalui transfer pricing (Beer dan Leoprick, 2015). Pihak afiliasi yang memiliki aset tidak berwujud mengurangi labanya lebih tinggi daripada pihak afiliasi yang tidak memiliki aset tidak berwujud (Beer dan Leoprick, 2015). Grup usaha menempatkan aset tidak berwujud di negara dengan tarif pajak rendah seperti Irlandia untuk mengalihkan pendapatan dari pihak afiliasi yang berdomisili di negara dengan tarif pajak tinggi (Barry, 2019). Transaksi afiliasi sehubungan aset tidak berwujud juga memiliki pengaruh negatif terhadap transfer pricing sebagaimana hasil penelitian Waworuntu dan Hadisaputra (2016) di Indonesia dan Merle et al. (2019) di Perancis. Pinjaman uang antar afiliasi digunakan untuk mengalihkan laba kepada pihak afiliasi di negara yang memiliki tarif pajak penghasilan lebih rendah (Cazacu, 2015). Semakin besar rasio hutang terhadap ekuitas maka semakin rendah laba entitas tersebut (Siregar et al. 2021).

\section{Tarif Pajak}

Transfer pricing dipengaruhi oleh perbedaan pajak antara kedua negara yang bertransaksi (Fong dan Ya, 2008). Perusahaan multinasional memiliki transaksi lebih besar dengan pihak afiliasi di negara dengan tarif pajak rendah (Rathke et al. 2020). Pihak afiliasi yang berdomisili di negara yang memiliki tarif pajak penghasilan lebih rendah akan memiliki laba yang lebih besar (Lo et al. 2010). Pengalihan laba ke negara yang memiliki tarif pajak penghasilan lebih rendah dilakukan dengan menyembunyikan informasi kepemilikan, melakukan reinvoicing, dan outsourcing (Feinschreiber dan Kent, 2012). Perusahaan multinasional di Kanada mengalihkan penghasilannya ke negara yang memiliki tarif pajak penghasilan lebih rendah dengan transaksi yang tidak memenuhi prinsip kewajaran (Hong 2010). Tarif pajak tempat perusahaan berdomisili sangat dipengaruhi oleh perilaku penetapan transfer pricing (Jarallah dan Kanazaki, 2011).

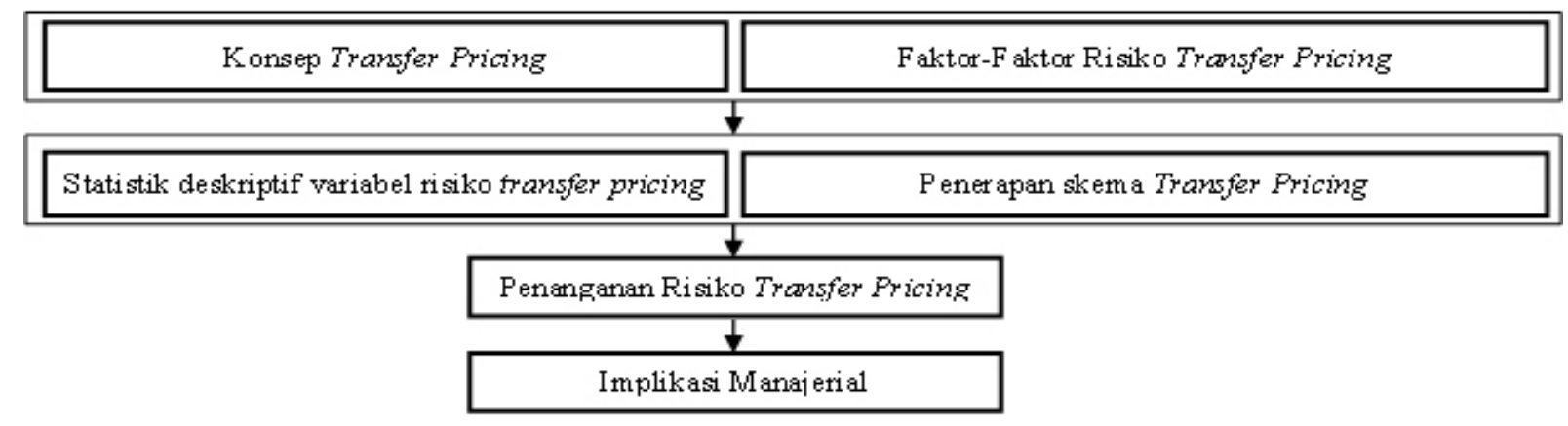

Gambar 1. Kerangka Pemikiran 
Kepemilikan asing

Semakin tinggi kepemilikan asing di suatu perusahaan, maka semakin besar kekuatan pemegang saham asing untuk mempengaruhi kebijakan yang diambil oleh perusahaan agar menguntungkan dirinya sendiri, termasuk strategi penetapan harga dan jumlah transfer pricing (Sari, 2012). Salah satunya tercermin dari kondisi perusahaan multinasional asing memiliki rasio beban bunga lebih tinggi daripada grup usaha dalam negeri (Li dan Tran, 2020).

\section{Statistik Deskriptif Faktor-Faktor Risiko Transfer Pricing}

Penelitian ini mencakup total 7.672 observasi yang berasal dari 1.096 perusahaan selama tujuh tahun pajak (2012-2018). Variabel-variabel yang dianalisis menggunakan statistika deskriptif adalah PEH (tingkat penjualan kepada pihak afiliasi); DMT (domisili mitra transaksi afiliasi dengan tarif pajak lebih rendah); dan KA (porsi kepemilikan asing langsung). Statistik deskriptif dapat dilihat pada Tabel 1.

Ketiga variabel pada Tabel 1 memiliki pengaruh terhadap risiko transfer pricing (Permen, 2020; Fong dan Ya, 2008; Sari, 2012). Tingkat penjualan kepada pihak afiliasi (PEH) menggambarkan nilai transaksi kepada pihak afiliasi baik yang berdomisili di Indonesia maupun diluar negeri. PEH merupakan salah satu indikator terkuat dalam pengukuran risiko transfer pricing (OECD, 2013). Jumlah observasi perusahaan yang memiliki transaksi penjualan kepada pihak afiliasi sebanyak 7.672 observasi. Hal ini berarti terdapat 7.672 observasi yang memiliki risiko transfer pricing di Indonesia. Variabel PEH menunjukan nilai maksimum dan rata-rata tertinggi, hal ini menunjukan bahwa transaksi afiliasi memiliki nilai transaksi terbesar dibandingkan nilai kepemilikan saham asing dan nilai transaksi kepada pihak afiliasi yang berdomisili pada negara yang memiliki tarif pajak penghasilan lebih rendah.

Domisili pihak afiliasi (DMT) menggambarkan nilai transaksi oleh pihak afiliasi di Indonesia dengan pihak afiliasi yang berdomisili pada negara dengan tarif pajak penghasilan lebih rendah. Perusahaan yang berdomisili pada negara yang memiliki tarif pajak penghasilan lebih tinggi akan melakukan pergeseran laba lebih besar daripada perusahaan yang berdomisili pada negara yang memiliki tarif pajak penghasilan lebih rendah (Matthews, 2002). Jumlah observasi perusahaan yang memiliki transaksi dengan pihak afiliasi yang berdomisili pada negara dengan tarif pajak lebih rendah sebanyak 2.985 observasi atau sebesar 38,9\%. Hal ini menunjukan bahwa terdapat 2.985 obeservasi yang memiliki risiko transfer pricing terkait dengan perusahaan yang memiliki transaksi afiliasi dengan pihak afiliasi yang berdomisili pada negara dengan tarif pajak lebih rendah. Indonesia termasuk negara yang memiliki tarif pajak penghasilan lebih tinggi daripada rata-rata tarif pajak dunia (KPMG, 2020). Kondisi ini memungkinkan bagi grup usaha untuk mengalihkan laba dari perusahaan yang berdomisili di Indonesia ke perusahaan yang berdomisili di negara dengan tarif pajak lebih rendah daripada Indonesia sehingga kewajiban pajak secara grup usaha dapat lebih rendah. Porsi kepemilikan asing (KA) menggambarkan nilai kepemilikan saham oleh entitas yang berdomisili di luar negeri. Perusahaan dengan pengendalian kepemilikan pihak asing memiliki risiko transfer pricing lebih tinggi daripada perusahaan yang tidak memiliki pengendalian kepemilikan pihak asing (Sung et al. 2016). Jumlah observasi perusahaan yang dimiliki oleh pihak asing sebesar 4.058 observasi atau sebesar $52,9 \%$. Hal ini menunjukan bahwa terdapat 4.058 observasi yang memiliki risiko transfer pricing terkait dengan perusahaan yang tergabung dalam grup usaha yang dimiliki oleh pihak asing. Suatu perusahaan yang dimiliki oleh pihak asing memiliki opsi-opsi untuk membuat suatu skema transfer pricing karena memiliki jaringan usaha secara global dengan entitas tersebar di berbagai negara yang memiliki perbedaan tarif pajak maupun kebijakan-kebijakan perpajakan. Perbedaan tersebut dapat digunakan oleh grup usaha global untuk memindahkan laba dari satu perusahaan ke perusahaan lainnya sehingga kewajiban perpajakan grup usaha tersebut dapat lebih rendah.

Nilai minimum pada DMT dan KA menunjukan nilai 0 , hal ini menunjukan tidak seluruh perusahaan pada penelitian ini yang memiliki ketiga variabel pada satu tahun pajak. Data penelitian yang memiliki satu variabel dalam satu tahun merupakan jenis data terbanyak pada penelitian ini dan data yang memiliki kombinasi tiga variabel menempati urutan kedua terbanyak. Hal ini menunjukan perusahaan pada penelitian ini menjalankan kombinasi skema transfer pricing yang berbeda-beda. Kombinasi variabel dapat dilihat pada Gambar 2. 
Tabel 1. Statistik deskriptif

\begin{tabular}{lcccccc}
\hline Variabel & Observasi & Mean & Median & Maksimum & Minimum & Std. Dev \\
\hline PEH & 7672 & 26.5220 & 26.521 & 34.3015 & 13.6414 & 1.8099 \\
DMT & 2985 & 9.4914 & 0,0000 & 33.6611 & 0,0000 & 12.0333 \\
KA & 4058 & 11.8531 & 16.3098 & 32.1358 & 0,0000 & 11.4668 \\
\hline
\end{tabular}

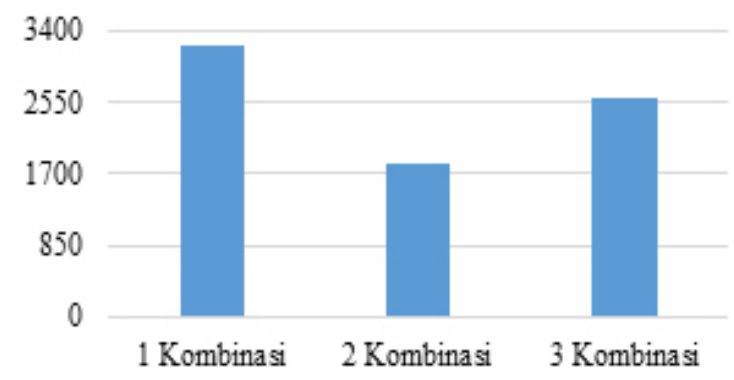

Gambar 2. Kombinasi variabel

Pemegang saham dalam negeri lebih besar daripada pemegang saham asing. Dari tahun 2012 sampai 2018, jumlah kepemilikan saham oleh pemegang saham dalam negeri terus mengalami peningkatan. Jumlah kepemilikan saham oleh pemegang saham asing juga mengalami peningkatan dari tahun 2012 sampai dengan Tahun 2015, namun sejak tahun 2016 jumlah kepemilikan saham asing mengalami penurunan sampai tahun 2018. Dapat disimpulkan skema transfer pricing bukan hanya dilakukan oleh perusahaan yang dimiliki oleh pemegang saham asing namun juga oleh perusahaan yang dimiliki oleh pemegang saham dalam negeri. Terdapat penurunan kepemilikan saham asing sejak tahun 2015 sampai 2018. Hal ini belum dapat disimpulkan terjadi penurunan kepemilikan asing karena data kepemilikan asing pada penelitian ini adalah kepemilikan asing secara langsung. Dimungkinkan terdapat aksi korporasi melaui merger maupun akuisisi sehingga kepemilikan asing secara langsung memang berkurang namun ultimate owner perusahaan tersebut tetap pihak asing. Mutasi kepemilikan saham dalam negeri dan asing dapat dilihat pada Gambar 3.

\section{Skema Transfer Pricing}

Transfer Pricing dengan Transaksi Afiliasi Berupa Penjualan/Pembelian

Olefirenko (2013) menjelaskan skema transfer pricing yang digunakan oleh MedTechnica 1 Ltd tahun 2010 sampai 2012. Skema transfer pricing MedTechnica 1 Ltd dapat dilihat pada Gambar 4. MedTechnica 1 Ltd merupakan perusahaan yang berdomisili di Rusia. MedTechnica 1 Ltd menjual produknya kepada pihak ketiga dan juga pihak afiliasi yang berdomisili di
Belarusia. Tarif pajak penghasilan di Belarusia adalah $18 \%$ sedangkan tarif pajak di Rusia adalah $20 \%$. MedTechnica 1 Ltd menjual hasil produksinya kepada pihak afiliasi hanya sebesar nilai produksi sehingga MedTechnica 1 Ltd tidak mencatatkan keuntungan atas transaksi kepada pihak afiliasinya, sebaliknya pihak afiliasi yang berdomisili di Belarusia mencatatkan keuntungan lebih tinggi karena membeli produk dari pihak afiliasi dengan nilai yang lebih murah. Dengan skema ini, MedTechnica 1 Ltd melakukan pergeseran laba ke pihak afiliasinya di Belarusia.

Transfer Pricing dengan Transaksi Afiliasi Berupa Aset Tidak Berwujud

Laura dan Michael (2008) menjelaskan kasus transfer pricing pada GlaxoSmithKline yang menggunakan skema transfer pricing melibatkan transaksi aset tidak berwujud berupa pembayaran royalti kepada pihak afiliasi. GlaxoSmithKline (GSK) adalah anak perusahaan yang dimiliki oleh Glaxo Group Limited (UKCO) yang berdomisili di Inggris. Grup Glaxo melakukan penelitian, pengembangan, pembuatan, dan distribusi produk farmasi di seluruh dunia. Salah satu produk farmasinya adalah ranitidine yang merupakan bahan aktif farmasi yang digunakan untuk mengobati sakit maag dengan merek Zantac.

GSK menandatangani dua perjanjian dengan anggota grup Glaxo yang mengizinkan GSK untuk menjual Zantac di Kanada. Perjanjian pertama adalah pengaturan lisensi dengan UKCO, dimana UKCO mengizinkan GSK untuk menjual produk dan menggunakan merek dagang grup Glaxo yang salah satunya adalah merek Zantac. Selain itu, UKCO juga mengijinkan GSK membeli bahan baku yang salah satunya adalah ranitidine dari perusahaan grup Glaxo. Perjanjian kedua adalah perjanjian pembelian bahan baku antara GSK dan pihak afiliasi yang berdomisili di negara Swiss yaitu SWISSCO. Dalam perjanjian tersebut, GSK dapat membeli ranitidine dari SWISSCO. SWISSCO membeli ranitidine yang dijual kepada pembayar pajak dari anak perusahaan UKCO yang berdomisili di negara Singapura (SINGCO). SINCO merupakan salah satu dari dua perusahaan grup Glaxo yang memproduksi ranitidine. 


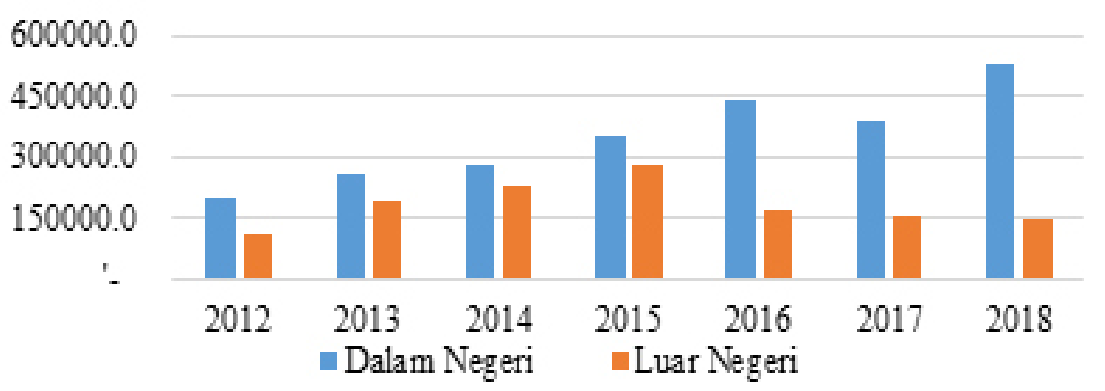

Gambar 3. Mutasi kepemilikan saham dalam negeri dan asing

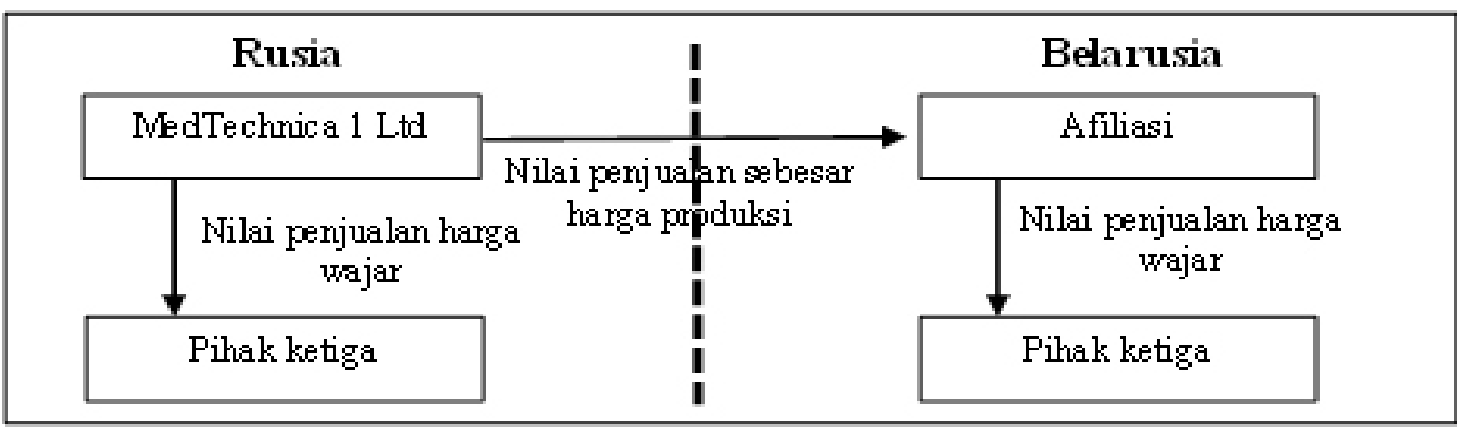

Gambar 4. Skema transfer pricing MedTechnica 1 Ltd

Dalam empat tahun perpajakan yang dipermasalahkan (1990 hingga 1993), wajib pajak membayar ke SWISSCO antara USD 1500 sampai USD 1650 per kilogram ranitidine. Selama periode yang sama, dua produsen generik lainnya yaitu Apotex dan Novopharm membeli ranitidine dari produsen pihak ketiga dengan harga mulai dari \$ 195 hingga \$ 300 per kilogram. Pada kasus ini, GSK membayar royalti sebesar $\$ \mathrm{x}$ kepada UKCO berdasarkan perjanjian lisensi dan \$ y kepada SWISSCO sebagai harga pembelian ranitidine berdasarkan perjanjian pembelian bahan baku. Perbedaan nilai yang signifikan atas pembelian ranitidine antar afiliasi dengan pembelian kepada pihak ketiga dan pembayaran royalti dari GSK kepada UKCO dapat memunculkan risiko transfer pricing karena GSK dapat mengalihkan laba nya kepada pihak afiliasinya sehingga kewajiban secara grup usaha dapat lebih minim. Skema transfer pricing grup Glaxo dapat dilihat pada Gambar 5.

\section{Transfer Pricing Berupa Pinjaman Afiliasi}

Sari dan Hunar (2018) menjelaskan skema transfer pricing pada Starbucks Coffee Company (UK) Limited yang berdomisili di Inggris. Starbucks UK menggunakan tiga transaksi antar afiliasi untuk meminimalkan kewajiban pajak grup usahanya. Skema pertama adalah transaksi pembelian biji kopi. Biji kopi dibeli melalui Starbucks Coffee Trading Company Sarl
(Starbucks Swiss) yang berdomisili di Swiss kemudian dikirim ke fasilitas roasting di seluruh dunia. Khusus untuk Starbuck UK, biji kopi tersebut dikirim dan di panggang di Belanda. Biji kopi tidak pernah secara fisik masuk ke Swiss tetapi dalam transaksinya, Starbuck Swiss menambahkan 20\% mark-up untuk penjualan biji kopinya. Mark-up dari anak Starbucks Swiss dan Starbucks Belanda terhadap biaya kopi Starbucks UK memiliki pengaruh yang signifikan terhadap tagihan pajak perusahaan Starbucks UK. Selain itu, tarif pajak perusahaan di Swiss sangat rendah yaitu sebesar 12\% dibandingkan dengan tarif pajak perusahaan Inggris sebesar 28\% pada tahun 2010, 26\% pada tahun 2011, dan 24\% pada tahun 2012. Dengan demikian, Starbucks UK dapat mengalihkan labanya ke Starbucks Swiss karena di negara Swiss tarif pajak lebih rendah dibandingkan di Inggris.

Kedua, Starbucks Corporation membebankan $6 \%$ biaya royalti atas penjualannya kepada pihak afiliasinya. Dalam kasus Starbuks EMEA, setengah dari royalti dibayarkan kepada kantor pusat EMEA yang berdomisili di Belanda dan setengahnya lagi ke perusahaan induk yang berdomisili di Amerika. Negara Amerika dan negara Belanda telah membebankan pajak atas pendapatan royalty tersebut. Namun, di Belanda terdapat aturan pajak bersifat rahasia yang memberikan tarif pajak yang sangat rendah kepada Starbucks. 


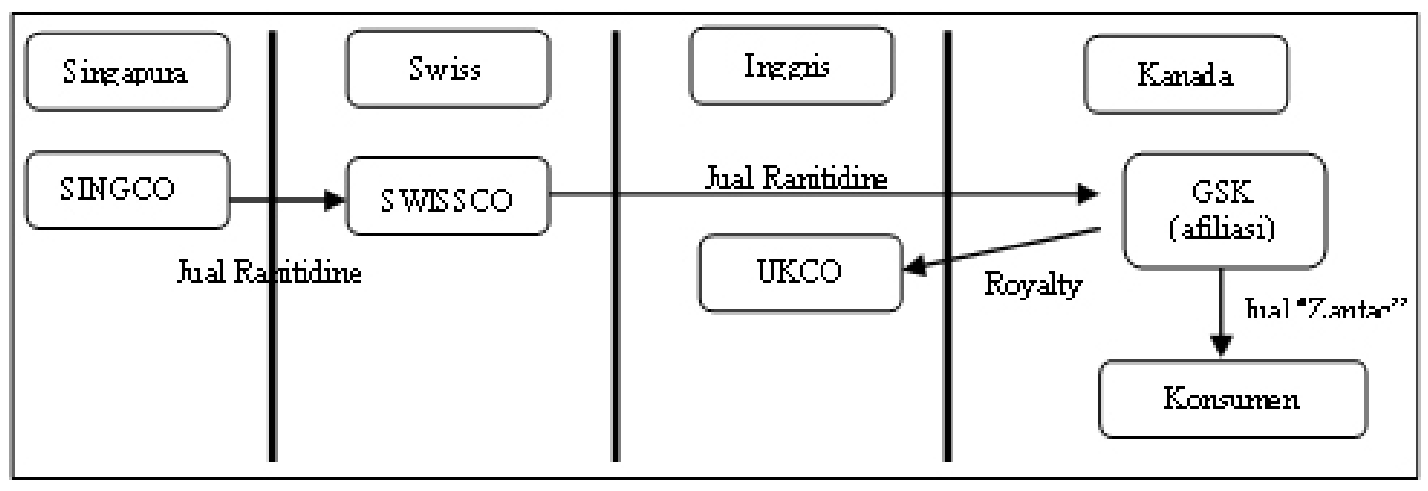

Gambar 5. Skema transfer pricing grup Glaxo

Ketiga, biaya bunga pinjaman yang dibayarkan Starbucks UK kepada Starbucks Corporation. Starbucks UK mencatatkan kerugian selama lebih dari 15 tahun sehingga Starbucks UK melakukan pinjaman kepada Starbucks Corportaion yang berdomisili di Amerika. Biaya bunga yang dibebankan oleh Starbucks Corportaion adalah LIBOR $+4 \%$ yang diyakini sebagai tingkat bunga tertinggi dibandingkan para pesaing. Dengan menggunakan tiga transaksi antar perusahaan ini, Starbucks UK dapat memindahkan labanya ke negara-negara dengan tarif pajak rendah dan dapat mencatatkan pendapatan kena pajak dengan nilai rugi di Inggris selama 15 tahun. Skema transfer pricing Starbucks Coffee Company (UK) Limited dapat dilihat pada Gambar 6.

\section{Transfer Pricing dengan Transaksi Afiliasi Berupa Jasa}

NTA(2013) juga memberikan gambaran skema transfer pricing dengan menggunakan transaksi jasa antar afiliasi. Skema transfer pricing dengan menggunakan transaksi jasa antar afiliasi dapat dilihat pada Gambar 7. Perusahaan P memiliki dua jenis transaksi afiliasi yaitu penjualan komponen "a" dan transaksi penyediaan jasa kepada perusahaan S. Perusahaan P menjual komponen "a" ke perusahaan $\mathrm{S}$ dan perusahaan $\mathrm{T}$ dengan harga yang sama dengan tahapan transaksi serta syarat transaksi yang sama. Untuk transaksi penyediaan jasa kepada perusahaan S, perusahaan $\mathrm{P}$ menyediakan tiga teknisi dari divisi manufakturnya ke perusahaan $\mathrm{S}$ selama sekitar dua bulan tiap tahunnya untuk melakukan pemeliharaan dan pemeriksaan fasilitas produksi atas produk A di perusahaan S. Selain itu ketiga insinyur tersebut juga melatih operator peralatan. Perawatan, inspeksi, dan layanan lain yang dilakukan oleh ketiga teknisi perusahaan $\mathrm{P}$ tidak unik dan mereka tidak menggunakan pengetahuan manufaktur perusahaan P. Perusahaan $\mathrm{S}$ tidak memberikan pertimbangan kepada perusahaan $\mathrm{P}$ untuk penyediaan layanan ini. Baik perusahaan $\mathrm{P}$ maupun perusahaan $\mathrm{S}$ tidak terlibat dalam transaksi penyediaan layanan serupa dengan pihak ketiga. Jenis jasa tersebut juga tidak ditemukan disediakan oleh perusahaan pihak ketiga. Dengan adanya transaksi afiliasi berupa penjualan dan penyerahan jasa kepada pihak afiliasi, maka terdapat risiko transfer pricing karena perusahaan $\mathrm{P}$ dapat mengalihkan labanya ke perusahaan S. Dalam kasus ini, perusahaan $\mathrm{P}$ harus membuktikan bahwa transaksi afiliasi kepada perusahaan $\mathrm{S}$ telah memenuhi prinsip kewajaran dan kelaziman transaksi.

\section{Penanganan Risiko Transfer pricing}

Indonesiamemilikibeberapaketentuanterkaitpenerapan skema transfer pricing untuk tujuan perpajakan. Pasal 18 ayat (3) UU (2008) menyatakan secara eksplisit bahwa Direktur Jenderal Pajak memiliki wewenang dalam penentuan kembali nilai penghasilan dan biaya dalam penghitungan kewajiban pajak penghasilannya bagi wajib pajak yang memiliki transaksi afiliasi dalam transfer pricing (UU 2008). Direktorat Jenderal Pajak (DJP) juga memiliki kewenangan untuk mengakses informasi baik berasal dari dalam negeri maupun pertukaran data antar negara (PP 2012). DJP telah melakukan perubahan infrastruktur pendukung pelaksanaan bisnis inti DJP dengan sangat progresif (Tambunan dan Anwar, 2019). Dengan demikian, DJP dapat mengembangkan sistem pengawasan transfer pricing berbasis risiko dengan perhitungan yang akurat dan penggunaan sumber daya yang efisien (OECD, 2013). 


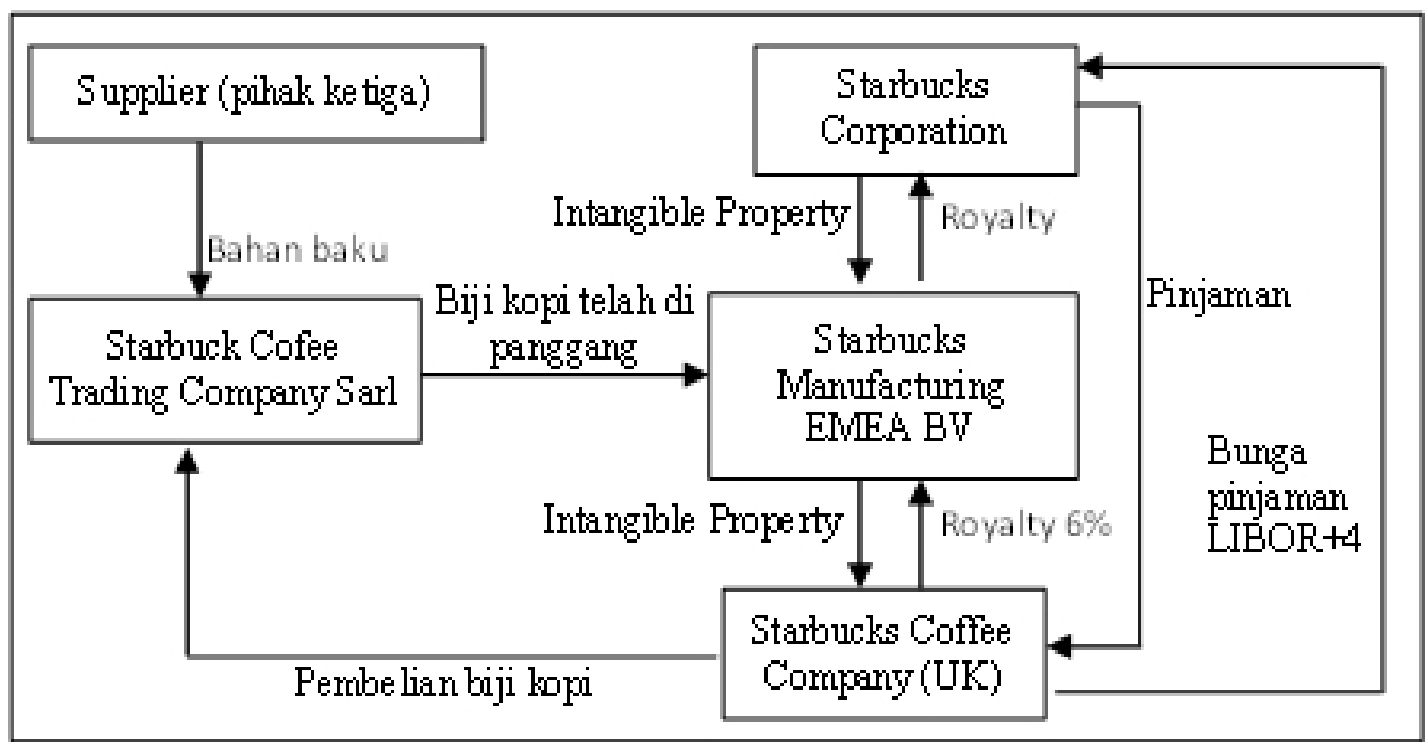

Gambar 6. Skema transfer pricing Starbucks Coffee Company (UK) Limited

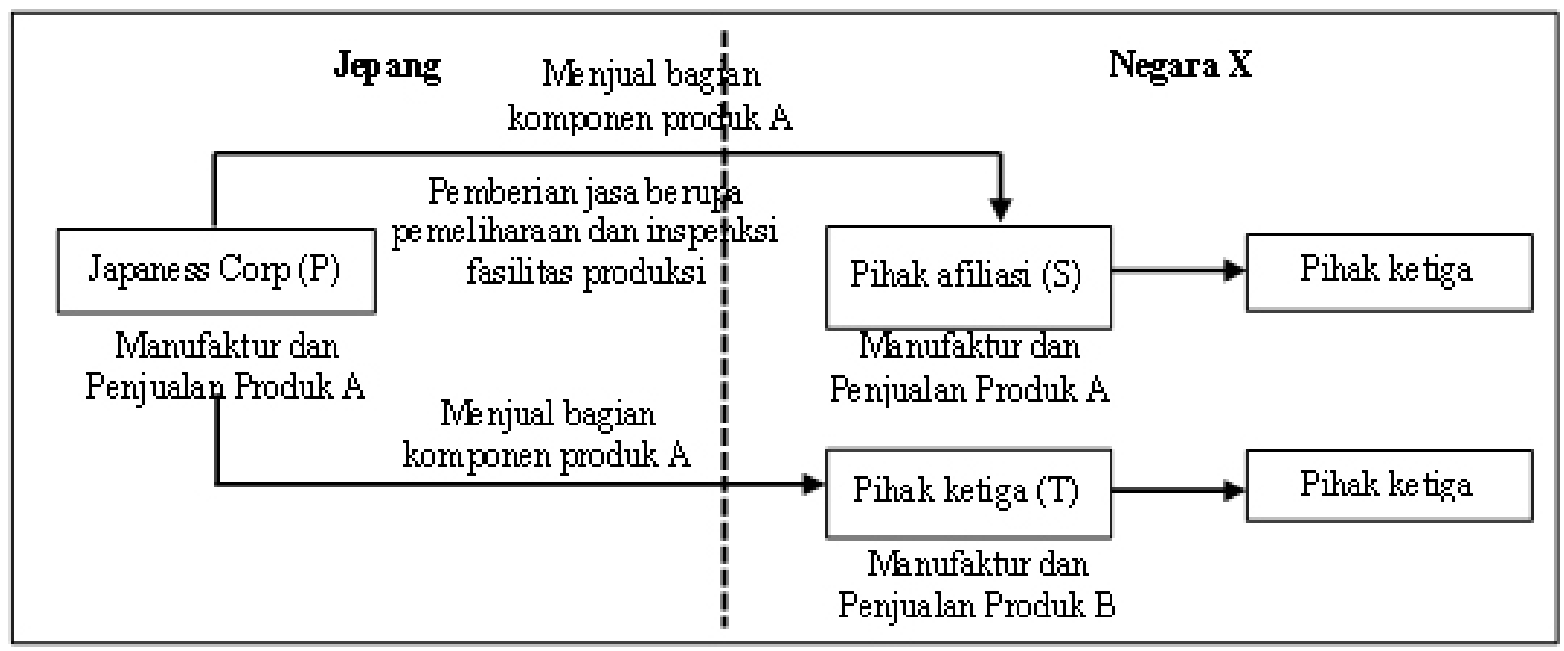

Gambar 7. Skema transfer pricing dengan menggunakan transaksi jasa antar

Indonesia telah menerbitkan Undang-Undang nomor 9 tahun 2017 untuk meningkatkan transparansi keuangan perusahaan dalam dan luar negeri (Sadiq et al. 2019). Berdasarkan ketentuan tersebut, DJP memiliki akses informasi data keuangan dari berbagai lembaga jasa keuangan yang kemudian informasi tersebut dipertukarkan antar otoritas pajak negara lain melalui perjanjian Automatic Exchange of Financial Account Information (AEOI) (UU 2017). AEOI memiliki pengaruh signifikan terhadap velume pertukaran data antar otoritas pajak di berbagai negara (Gupta 2019). AEOI mempengaruhi kemampuan otoritas pajak dalam menjalankan fungsi penilaian risiko, menejemen data dan pemeriksaan (Gueydi dan Abdellatif, 2019).
Pertukaran informasi juga dapat dilakukan melalui instrumen bilateral dengan dasar hukum Perjanjian Penghindaran Pajak Berganda (P3B) (Darussalam dan Septriadi, 2017). Bagi yang tidak memiliki perjanjian P3B, dapatmelakukan pertukaran informasiberdasarkan Tax Information Exchange Agreement (TIEA Model) (Darussalam dan Septriadi, 2017). Pemerintah Amerika Serikat juga menerbitkan peraturan yang disebut Foreign Account tax Compliance Act (FATCA) yang dirancang untuk pencegahan serta mendeteksi praktik penghindaran pajak secara ilegal oleh warga negara Amerika Serikat melalui lembaga-lembaga jasa keuangan asing (Darussalam dan Septriadi, 2017). 


\section{Implikasi manajerial}

Direktorat Jenderal Pajak (DJP) perlu memberikan perhatian lebih terhadap perusahaan yang memiliki berbagai jenis transaksi afiliasi, perusahaan yang bertransaksi dengan pihak afiliasi pada negara dengan tarif pajak lebih rendah dari Indonesia, dan perusahaan dengan kepemilikan asing yang tergabung dalam grup usaha terkait risiko transfer pricing. DJP juga perlu melakukan pengawasan atas skema transaksi afiliasi terkait dengan penjualan, aset tidak berwujud dan penyerahan jasa karena skema-skema ini digunakan dalam praktik transfer pricing. Perusahaan yang memiliki transaksi afiliasi juga perlu melakukan pengkuran pemenuhan the arm's length principle atas skema transfer pricing yang dijalankan. Transaksi afiliasi yang tidak memenuhi the arm 's length principle memiliki konsekuensi hukum sesuai ketentuan yang berlaku. Penelitian selanjutnya dapat menganalisis determinan risiko dan skema-skema transfer pricing yang belum tercakup pada penelitian ini sehingga mendapatkan gambaran lebih lengkap terkait dengan skema transfer pricing untuk penghindaran pajak.

\section{KESIMPULAN DAN SARAN}

\section{Kesimpulan}

Transfer pricing harus memenuhi the arm's length principle sehingga sesuai dengan ketentuan yang berlaku. Faktor-faktor yang mempengaruhi risiko transfer pricing adalah penjualan kepada pihak afiliasi, transaksi dengan pihak afiliasi yang berdomisili pada negara dengan tarif pajak lebih rendah, dan kepemilikan asing. Transfer pricing dapat diimplementasikan dengan skema transaksi afiliasi berupa penjualan, aset tidak berwujud, pinjaman dan jasa. Penanganan risiko transfer pricing dapat dilakukan dengan kebijakan ketentuan perpajakan domestik, kerjasama antar otoritas pajak dan pembangunan sistem pengawasan transfer pricing berbasis risiko. Dalam perumusan kebijakan risiko transfer pricing, Direktorat Jenderal Pajak (DJP) perlu memprioritaskan pengawasan terhadap wajib pajak yang dimiliki oleh pihak asing, memiliki satu atau lebih transaksi afiliasi, dan domisili lawan transaksi afiliasi pada negara dengan tarif pajak penghasilan lebih rendah. Selain itu, data dan informasi yang bersumber dari Automatic Exchange of Financial Account Information (AEOI), Perjanjian Penghindaran Pajak Berganda (P3B) dan akses data dalam negeri dapat dimanfaatkan oleh DJP dalam pengembangan algoritma sistem pengawasan berbasis risiko transfer pricing. Dengan sistem tersebut, diharapkan DJP dapat mengidentifikasi wajib pajak yang memiliki risiko transfer pricing tertinggi sampai terendah.

\section{Saran}

Penelitian selanjutnya dapat menganalisis faktor-faktor risiko dan skema-skema transfer pricing yang belum tercakup pada penelitian ini sehingga mendapatkan gambaran lebih lengkap terkait dengan skema transfer pricing untuk pengalihan laba.

\section{UCAPAN TERIMAKASIH}

Penelitian ini dikukung oleh Lembaga Pengelola Dana Pendidikan (LPDP) dengan Letter of Guarantee (LoG) nomor KET-904/LPDP.4/2019 tanggal 23 Mei 2019.

\section{DAFTAR PUSTAKA}

Adegbite TA, Bojuwon M. 2019. Corporate tax avoidance practices: an empirical evidence from nigerian firms. Studia Universitatis Babes-Bolyai 64(3):39-53.

Amidu M, Coffie W, Acquah P. 2019. Transfer pricing, earnings management and tax avoidance of firms in Ghana. Journal of Financial Crime 27(1):235259.

Barker J, Asare K, Brickman S. 2017. Transfer pricing as a vehicle in corporate tax avoidance. Journal of Applied Business Research 33(1):9-16.

Barry F. 2019. Aggressive tax planning practices and inward-FDI implications for ireland of the new US corporate tax regime. The Economic and Social Review 50(2):325-340.

Beer S, Loeprick J. 2015. Profit shifting: drivers of transfer (mis)pricing and the potential of countermeasures. International Tax and Public Finance 22(3):426-451.

Cazacu (Neamţu) AL. 2015. An approach on links between transfer pricing and tax havens. Annals of the University of Petroşani. Economics 15(1):51-58.

Darussalam, Septriadi D, Kristiaji BB. 2013. Transfer pricing Ide, Strategi, dan Panduan Praktis Dalam Perspektif Pajak Internasional. Jakarta: 
PT Dimensi Internasional Tax.

Darussalam, Septriadi D. 2017. Perjanjian Penghindaran Pajak Berganda - Panduan, Interpretasi dan Aplikasi. Jakarta: PT Dimensi Internasional Tax.

Feinschreiber, Kent. 2012. Transfer pricing Handbook, Guidance on The OECD Regulations. New Jersey: John Wiley \& Sons, Inc.

Fong SW, Ya CW. 2008. Brand proliferation and interbrand competition: The strategic role of transfer pricing. Journal of Economic Studies 35(3):278292.

Gueydi S, Abdellatif MM. 2019. The transformation of tax administration functions in the automatic exchange of information era - a developing country's perspective. eJournal of Tax Research 16(3): 780-800.

Gupta R. 2019. Shifting sands: the unravelling of international exchange of information and disclosure rules on tax matters. eJournal of Tax Research 16(3): 655-678.

Huda MK, Nugraheni N, Kamarudin K. 2017. The problem of transfer pricing in indonesia taxation system. International Journal of Economics and Financial Issues 7(4): 139-143.

Hoffman MD. 2001. International taxation and the income shifting behaviour of multinational enterprises [disertasi]. Edmonton: University of Alberta.

Hong Q. 2010. International taxation and incomeshifting behaviour of multinational corporations [thesis]. Toronto: University of Toronto.

Jarallah S, Kanazaki Y. 2011. A review of empirical studies on transfer pricing manipulation. Journal of International Logistics and Trade 9(2):3-31.

Kiesewetter D, Steigenberger T, Stier M. 2018. Can formula apportionment really prevent multinational enterprises from profit shifting? The role of asset valuation, intragroup debt, and leases. Zeitschrift für Betriebswirtschaft 88(9):1029-1060.

Li XE, Tran A. 2020. An empirical study on crossborder profit shifting in Australia. eJournal of Tax Research 17(2): 193-232.

Li Y, Luo Y, Wang J, Foo CT. 2016. A theory of managerial tax aggression: evidence from China, 2008-2013 (9702 observations). Chinese Management Studies 10(1):12-40.

Lo AWY, Wong RMK, Firth M. 2010. Tax, financial reporting, and tunneling incentives for income shifting: an empirical analysis of the transfer pricing behavior of chinese-listed companies. The Journal of the American Taxation Association 32(2):1-26.

Matthews TA. 2002. Does home -country taxation of foreign earnings affect cross -jurisdictional income shifting? [thesis]. Ontario: University of Waterloo.

Merle R, Al-Gamrh B, Ahsan T. 2019. Tax havens and transfer pricing intensity: Evidence from the French CAC-40 listed firm. Cogent Business \& Management 6: 1647918. https://doi.org/10.108 0/23311975.2019.1647918.

[OECD] Organisation for Economic Co-operation and Development. 2012. Dealing Effectively with the Challenges of Transfer Pricing. Paris: OECD Publishing.

[OECD] Organisation for Economic Co-operation and Development. 2013. Draft Handbook on Transfer pricing Risk Assessment. Paris: OECD Publishing.

[OECD] Organisation for Economic Co-operation and Development. 2017. OECD Transfer pricing Guidelines for Multinational Enterprises and Tax Administrations 2017. Paris: OECD Publishing.

Olefirenko E. 2013. Transfer pricing in a case company MedTechnica 1 [tesis]. Helsinki: University of Haaga-Helia.

[Permen] Peraturan Menteri Keuangan Nomor 22/ PMK.03/2020 tentang Tata Cara Pelaksanaan Kesepakatan Harga Transfer (Advance Pricing Agreement). 2020.

[PP] Peraturan Pemerintah Republik Indonesia nomor 31 tahun 2012 tentang pemberian dan penghimpunan data dan informasi yang berkaitan dengan perpajakan. 2012.

Rathke AA, Rezende AJ, Watrin C. 2020. The impact of countries' transfer pricing rules on profit shifting. Journal of Applied Accounting Research 22(1): 22-49.

Sadiq K, Sawyer A, McCredie B. 2019. Jurisdictional responses to base erosion and profit shifting: a study of 19 key domestic tax systems. eJournal of Tax Research 16(3): 737-761.

Sari DK ,Utama S, Rossieta H. 2017. Tax avoidance, related party transactions, corporate governance and the corporate cash dividend policy. Journal of Indonesian Economy and Business 32(3): 190-208.

Sari N, Hunar RS. 2018. Analysis method of transfer pricing used by multinational companies related to tax avoidance and its consistencies to the 
arm's length principle (case study: starbucks corporation). Journal of Business Strategy and Execution 8(1):70-96.

Sari RC. 2012. Tunneling dan Model Prediksi: Bukti Empiris Pada Transaksi Pihak Berelasi [disertasi]. Yogyakarta: Universitas Gadjah Mada.

Siregar AAP, Achsani NA, Sasongko H. 2021. Pengaruh tax amnesty terhadap profitabilitas perusahaan yang terdaftar di Bursa Efek Indonesia. Jurnal Aplikasi Bisnis dan Manajemen 7(1):86. https:// doi.org/10.17358/jabm.7.1.86.

Stoddard LJ, Templeton MD. 2008. Current cases tax court of canada. Canadian Tax Journal. 56(4):923 - 56.

Tambunan ME, Siregar H, Manurung AH, Priyarsono DS. 2016. Related party transactions and firm value in the business groups in the indonesia stock exchange. Journal of Applied Finance \& Banking 7(3):1-20.
Tambunan MR, Anwar R. 2019. Transformasi budaya organisasi otoritas perpajakan indonesia menghadapi era ekonomi digital. Jurnal Aplikasi Bisnis dan Manajemen 5(2):253. https://doi. org/10.17358/jabm.5.2.253.

[UU] Undang-Undang nomor 36 tahun 2008 tentang perubahan keempat atas undang-undang nomor 7 tahun 1983 tentang pajak penghasilan.

[UU] Undang-Undang nomor 9 tahun 2017 tentang penetapan peraturan pemerintah pengganti undang-undang nomor 1 tahun 2017 tentang akses informasi keuangan untuk kepentingan perpajakan menjadi undang-undang.

Waworuntu SR, Hadisaputra R. 2016. Determinants of transfer pricing aggressiveness in Indonesia. Pertanika Journal of Social Sciences \& Humanities 24S:95-110. 